Article

\title{
SME Managers' Perceptions of Sustainable Marketing Mix in Different Socioeconomic Conditions-A Comparative Analysis of Sri Lanka and Poland
}

\author{
Magdalena Kowalska \\ Department of Marketing, Faculty of Management, University of Szczecin, 70-453 Szczecin, Poland; \\ magdalena.kowalska@usz.edu.pl; Tel.: +48-5-0134-2734
}

Received: 2 October 2020; Accepted: 17 December 2020; Published: 20 December 2020

\begin{abstract}
Current changes in the business environment mean that the pursuit of economic development-without accounting for social welfare and environmental constraints-is replaced by the concept of sustainable development. Enterprises, in order to meet market requirements, adopt sustainable marketing as part of their strategy to provide long-term benefits in the social, economic, and environmental dimensions. The article aims to assess the differences in the use of marketing mix tools (5P) according to the concept of sustainable development in countries with different socioeconomic conditions. The empirical study was based on 262 questionnaires conducted among small and medium-sized enterprises (SMEs) operating in two different countries, i.e., 150 companies operating in Poland (as an example of a developed country) and 112 in Sri Lanka (as an example of a developing country). The obtained results show that there are statistically significant differences between the analyzed markets in terms of implementing sustainable marketing tools. The results allow us to conclude that the sustainable marketing mix activities are significantly more important for SEM managers in Sri Lanka than in Poland.
\end{abstract}

Keywords: sustainable marketing; sustainable marketing mix; sustainable development; Sri Lanka; Poland

\section{Theoretical Background}

The changing business environment, which is not only related to the increase in competition, the development of new technologies, or growing customer demands but also to the increase in pollution and the degradation the natural environment, strongly influences the functioning of enterprises [1]. In response to the changing business ecosystem in which they operate, enterprises should provide new business models to meet market requirements and adapt to environmental changes [2,3]. Corporate strategies oriented only at increasing sales and consumption have ceased to bring the expected results. The success of today's business should result from long-term sustainable development that takes into account environmental, economic, and social dimensions [4-6]. Sustainable development has become one of the most popular development concepts that have received global acceptance [7]. The growing popularity of the sustainable development strategy indicates that enterprises have realized that being more sustainable can create a new source of competitive advantage [8-10], increase the value of the company $[5,11]$, or positively affect consumer loyalty to the brands [12-15]. Due to the changes taking place, enterprises are faced with the need to redefine their strategies, particularly marketing strategies.

The emergence of the concept of sustainable development has influenced a new perspective in creating, communicating, and delivering value not only to customers but also to other entities of the 
business environment. The literature emphasizes the significant role of marketing in implementing the concept of sustainable development as the most prominent component of relationships between a company and its environment and an important factor to value creation [16,17]. Building marketing strategies taking into account development assumptions changed the implementation of individual marketing functions and redefined marketing tools, which in the conventional sense focused strongly on the interests of the seller rather than the sustainable buyer, which was criticized by researchers $[18,19]$. Until then, marketing was often perceived as sales, including activities stimulating consumerism, shortening product life cycles, manipulating consumer behavior, or creating needs [20,21]. Defining marketing as activities to satisfy the needs and desires of buyers through the exchange process has increased negative perceptions of marketing. For an increasingly affluent and consuming world, meeting such needs without considering their impact on the ecosystem may deprive future generations and a part of the present generation of the opportunity to satisfy their own needs and desires [22]. For these reasons, marketing was considered contradictory to the concept of sustainable development [23]. A milestone for marketing was the Commission Brundtland Report, published in 1987. The main conclusion of the report was that meeting the needs of the current generation must not jeopardize the ability of future generations to meet their own needs and this was an impulse to change the concept of marketing towards sustainable development [24].

Researchers [25,26] emphasize the importance of research conducted in the last decade and the growing interest in corporate social responsibility (CSR) and sustainable marketing. Both concepts, although related to the responsibility for the company's actions, differ significantly. The main difference lies in their main assumptions, as CRS includes activities related to the way of using the generated funds to meet the needs of contemporary society, whilst sustainable marketing focuses on how funds are earned and how they work in an intergenerational horizon [27]. Sustainable marketing should therefore be seen as marketing that is not only a part, but above all a supporting element of sustainable economic development. Within the framework of sustainable development, marketing has undergone a three-step evolution [28] including (1) ecological marketing-focusing on environmental problems such as air pollution, depletion of natural resources, and the impact of fertilizers and agricultural pesticides; (2) environmental marketing-focusing on developing modern, environmentally friendly "clean" technologies targeted at the "green customer segment"; (3) sustainable marketing-focusing activities on responsible economic and social development.

The literature provides many definitions of sustainable marketing. Belz [29] defines sustainable marketing as an act of building and maintaining sustainable relationships with customers, the social environment, and the natural environment. Kirchgeorg and Winn [30] show a managerial point of view, defining sustainable marketing as planning, coordination, implementation, and controlling of all market transactions in such a way to ensure that the needs of the current and potential customers are met on a sustainable basis toward corporate objectives, whilst contributing to reducing environmental and social impacts and restoring social and environmental health. It is common to define sustainable marketing as a process of creating, communicating, and delivering value to customers, concerning environmental and social aspects [31,32], emphasizing the importance of building long-term relationships with customers, which are not only beneficial for business but also for society and the environment [33]. In this approach, it can be noticed that the most important becomes human and the narrative environment.

The concept of the marketing mix, along with the concept of sustainable development, plays an important role in the responsible strategy of business activities. Traditional marketing mix tools do not take into consideration and help activities for sustainable development, hence Kotler [34] emphasizes that marketing should be "reinvented" to achieve environmental sustainability. The answer to this call is to redefine the tools of the marketing mix, called sustainable marketing mix, including sustainable product, balanced price, sustainable distribution, sustainable promotion, and sustainable people (employees). The use of sustainable marketing tools in the business provides a new place for marketing in the modern market. A review of the literature shows that sustainable marketing is increasingly attracting the interest of theoretical research, but there is still little empirical research on the subject. 
The literature emphasizes the existing research gap in this area $[1,35]$ because the research conducted is fragmented and covers only selected areas of marketing activities. An analysis of literature in the field of marketing and management indicates that there is research into the implementation of sustainable development in individual marketing mix tools, regarding product development [13,36-39], the price [32,40-42], distribution [14,40,43-45], or promotional activities [46-49]. However, these studies are often selective, limited to one or few tools that are often studied from a perspective of clients' attitudes and preferences in the context of sustainable development $[49,50]$. The reasons for the lack of comprehensive research on sustainable marketing, including sustainable marketing mix, should be seen as the relatively new nature of this research area, which requires further supplements and improvement, both through theoretical and empirical research. The book edited by Rudawska [51] has a significant impact on this area. The authors of this publication presented the research result on the development of marketing mix tools from the perspective of enterprises implementing a new business model considering sustainable development. The book presents an original concept of defining each of the sustainable marketing mix tools, which was adopted by the author in this study. A company that implements sustainable marketing is one in which the principles of transparency cover all tools for influencing the market, including product, price, distribution, and promotion. The article proposes the research within the extended area of 5P, taking into account the company staff as a tool of a significant impact on the functioning of the company in the market. In the concept of sustainable marketing, company managers build long-term relationships not only with the environment but also with employees, because they are one of the company's most valuable assets [52].

Activities in the field of sustainable development should not only be included in the strategies of large companies, but should also be implemented by small and medium-sized enterprises (SMEs). The literature discusses the implementation of sustainable marketing in large enterprises, however, a gap is noticed in the research on micro- and SMEs [53,54]. At the same time, the necessity to adopt different actions than those tailored for large enterprises is emphasized when implementing sustainable development in the structures of these entities [55]. Several researchers emphasize that ways of implementing sustainable development for SMEs have not yet been widely explored, which may have an impact on the slow pace of implementation of the sustainable development strategies [56]. Paying less attention to the implementation of sustainable solutions in smaller enterprises may result from overlooking the fact that these entities can also be a threat to the natural environment [57]. However, due to the large number of these entities in the market, their influence is significant, and abandonment of proecological and prosocial activities may have huge negative consequences. Additionally, the slowness of SMEs in implementing the sustainable development strategy may refer to the lack of often smaller financial resources that can be invested in the development of new technologies or activities for the environment or community [56], which exacerbates the uncertain return on investment, which is delayed in time [48]. The arguments cited show that the factors influencing the acceptance of sustainable development by entities of various sizes are different, therefore the actions that should be taken also require appropriate adjustments. This is confirmed by the research conducted by Wang et al. [58] that shows that different sizes of enterprises need different actions related to sustainable marketing, including the selection of sustainable marketing mix tools. The identified gap as the lack of complete activities of SMEs to implement sustainable marketing mix tools seems important to the author to include in the research area.

The phenomena of overexploitation of natural resources, the production of an increasing quantity of waste and harmful substances, and the increase in the number of people and the scale of consumerism observed today on the global market are causing irreversible degradation of the natural environment and a deterioration in the quality of social life [59]. In particular, it is of great importance to the food and beverage market, as the production processes of this assortment have a significant impact on environmental degradation and the resulting social problems. Reisch, Eberle, and Lorek [60] see these negative effects in the industrialization and globalization of agriculture and food processing; the change of consumer preferences to more dietary and animal protein; the modern food styles that demand 
heavily processed products; the increasing global gap between the rich and poor; the recurring absence of food security during the production of big quantities of food. On the other hand, the food and drink sector has a unique role in expanding economic opportunity as it is universal to human life and health. The study presented in this article was conducted among SMEs operating in the food and beverage industry in the region of Pacific Asia (Sri Lanka) and Europe (Poland) to show economically diverse regions. The legitimacy of narrowing down the research on sustainable marketing to a specific sector is emphasized in the research by Lee [61]. The choice of this sector results from the fact that it is one of the largest production sectors of the world economy, which is an integral part of the world's economic, social, and cultural mix. The Pacific Asia is the largest region in the global food and beverages market, accounting for $42 \%$ of the market in 2019 [62]. In Europe, the food and beverage industry is the EU's biggest manufacturing sector in terms of jobs and added value. It is the largest manufacturing sector in the EU, representing $15.6 \%$ of share turnover, and employing 4.25 million employees. It should be emphasized that $99 \%$ of enterprises operating in the sector belong to SMEs [63]. When considering sustainable development in the global dimension, one should notice serious problems that may arise, especially in the application dimension or a different perception of its political, social, and economic effects in various parts of the globe. In the developed countries, it is seen as a holistic concept of understanding the relationship between the environment, economy, and society, whilst from the perspective of the developing countries of Asia, it can be seen as an attempt to impose the dominance of Western thinking to modernize the region. Many Asian economies are still under more or less strict state control, the practice of internal reforms often deviates from Western expectations, and the widening gap between the rich and lower earners can be a serious obstacle to future growth for all of them [64].

Increased consumption contributes to overproduction, and thus significantly exploits the natural environment. It is clear that more responsible consumption, to an extent necessary to mitigate anthropogenic climate change, cannot be achieved solely by relying on consumers to change their purchasing preferences and behavior [65] or on rules imposed by public authorities. To deal with these existing problems, special attention should be paid to the concept of sustainable development, which influences the philosophy of business behavior, shaping their activities in the area of management and marketing. Responsible marketing activities play a significant role both in reducing negative effects and promoting proecological and prosocial consumer behavior. The growing awareness and educating customers in the field of sustainable development make it necessary to incorporate sustainability into the marketing strategies of companies operating in the food and drink industry to remain competitive on the market. The purpose of implementing a sustainable marketing mix is to introduce food products to the market that will meet the needs and desires of buyers with a minimal impact on the natural environment. The research conducted so far in the field of sustainable development in the food market focuses mainly on the sources of inequality in food and beverage production [62], the creation of a sustainable supply chain in the food and beverage industry [66], the willingness of customers to pay higher prices for sustainable offers $[67,68]$, or sustainability in terms of the product innovation strategy [69]. However, there is a lack of research on the implemented marketing mix tools in this sector, hence the decision to fill this gap.

The economic development of the country and its culture have a significant impact on the decisions made by consumers, and thus on the functioning of enterprises. Researchers emphasize that the low level of income influences the choices of less healthy and more processed foods [70]. The development and the policy of the country determine its environmental awareness, including the tax requirements and restrictions imposed on enterprises, including those resulting from the necessity of certain behaviors influencing care for the environment and society. Yet another factor determining activities in the food market is culture. The influence of culture on operations in international markets is the contextual model proposed by Hall in 1960 [71], concerning the division into communication:

- with a low role of context in the reception of the message-in which the society is characterized by individualism; "I" dominates over "we". These cultures are based on spoken and written 
language and emphasize the exchange of facts and information. Countries belonging to this group are Sweden, countries of Western and Central Europe, countries of North America;

- with the high role of context in the reception of the message, characterized by collectivism- "we" dominates over "I". These cultures are based on body language, social position, knowledge of a person, and mutual relations. Countries belonging to this group are Arab states, Latin American states, and most Asian states.

The analysis of the literature shows a low research output identifying the impact of the socioeconomic development of the country on implementing the concept of sustainable marketing.

The above considerations indicate that the topic discussed in the article is current, interesting and has yet to be insufficiently researched. This article provides an opportunity to expand knowledge in the field of research and responds to the identified research gap. Firstly, it broadens theoretical knowledge on the implementation of sustainable marketing tools that are adapted to the realities of SMEs operating in the food and beverage industry. Secondly, it broadens knowledge on how the tools are used in practice by small and medium-sized enterprises in the liquor and drinking industry. Thirdly, it is the first article that compares the implementation of sustainable marketing tools in a diverse socioeconomic environment, thus showing the differences and similarities in the activities of companies in the field of implementing sustainable marketing in various markets. Lastly, it enables the identification of activities that are insufficiently implemented in enterprises, which may be a good indication for improvement for the future. Considering the above, the main goal of the article is to evaluate the marketing mix tools (5P) used by SMEs based on the concept of sustainable development and to identify the differences in their use by SMEs operating in socioeconomically diverse markets of Poland (as an example of a developed country) and Sri Lanka (as an example of a developing country).

\section{Materials and Methods}

\subsection{Research Context}

The article mainly aims to assess the differences in the use of marketing mix tools (5P), taking into account the concept of sustainable development, by enterprises operating in diverse socioeconomic countries. To achieve the goal, the study focuses on a country with a developed economy in Europe and a developing country in Asia. The countries included in the study were selected based on the analysis of data from the International Monetary Fund [72]. Two countries were included in the study: Poland (as an example of a highly developed country in Europe) and Sri Lanka (as an example of a developing country in Asia). The diversity of the location of countries on different continents is dictated by a different culture present in the identified countries. Poland and Sri Lanka differ from each other as indicated by the analysis of the country's culture conducted with the use of variables proposed in the Hofstede model [73].

The Polish culture houses a "contradiction"; although it is highly individualist, the Polish need a hierarchy, in which everybody has their place. This combination of a high score on the Power Distance Index (68) and a high score on the Individualism Index (60) creates a specific "tension" in this culture. Poland scores 64 on the Masculinity dimension, and according to Hofstede, it may be regarded as a Masculine society. In such countries people "live to work", and the emphasis is on equity, competition, and performance. Poland has a high Uncertainty Avoidance Index (93), which means that this country maintains rigid codes of beliefs and behaviors and is intolerant of unorthodox behaviors and ideas. Poland's low Long-Term Orientation score of 38 means that Polish society is more normative than pragmatic. People show respect for traditions, and simultaneously a relatively small propensity to save for the future as well as a focus on achieving quick results. In the context of sustainable development, this may indicate a lack of respect for long-term environmental goals. Polish societies tend towards cynicism and pessimism, as indicated by the low score of 29 on the Indulgence Index.

Considering the first cultural dimension, the Power Distance Index, one can conclude that Sri Lanka (80) is a more hierarchical society than Poland (68). This means that people accept a hierarchy 
both in society and at work. A low score of 35 on the Individualism Index means that Sri Lanka is considered a collectivistic society. This can be seen in the close, long-term commitment to the member 'group'. In this approach, the concern for the environment and natural resources for the next generations may also be demonstrated at a higher level. Sri Lanka has a very low score (10) on the Masculine dimension and thus it is considered a Feminine society. In this type of culture, the focus is on "working to live", people value equality, solidarity, and quality in their working lives. Hence, the concern for the environment as a human-friendly place is also of great importance, which should be respected for long-term benefits. Focus is on well-being and status is not shown or emphasized. Sri Lanka is a culture with a moderately low Uncertainty Avoidance Index (45), low-stress levels, and low nervousness because Sri Lankans are more tolerant of uncertainty and ambiguity.

The study assumes that enterprises operating in the developed countries have greater experience in and awareness of the sustainable development strategy in their business activities. In this approach, companies operating on this market more often implement the concepts of sustainable marketing based on newly defined marketing mix tools based on the environmental and social aspects. In contrast, enterprises operating in the developing markets, characterized by a lower level of socioeconomic development, having less experience, and thus lower awareness of the need to implement the concept of sustainable marketing, undertake activities that use the sustainable marketing mix to a lesser extent. The analysis of the literature shows that there is a research gap regarding the use of sustainable marketing mix (5P), taking into account the socioeconomic development of the country. To fill this gap, the authors of the study asked the following research questions:

RQ 1. To what extent do companies implement marketing tools in consideration of sustainable development?

RQ 2. What are the differences in the use of sustainable marketing mix tools by companies in the developed countries of Europe and the developing countries of Asia?

Literature analysis leads to the conclusion that the majority of research is carried out on large enterprises, with little research conducted on SMEs. Wang et al. [58] emphasizes that entrepreneurial size determines other sustainable marketing activities. Given that SMEs are one of the most important drivers of economic development in countries with a market economy-they are responsible for stimulating development, innovation, and entrepreneurship, and are more flexible than large companies in accepting changes [74] - the conducted study focuses on this market segment. In response to the identified research gap, the article aims to provide information to SMEs on implementing the concept of sustainable marketing.

The study proposed in this article was conducted among SMEs operating in the food and beverage industry. This sector was chosen since it is one of the world's leading manufacturing sectors, and the analysis of the results obtained from managers of enterprises operating in a given sector will provide the basis for a more detailed insight.

\subsection{Sample and Data Collection}

The research results presented in this article are part of a wider project on the implementation of sustainable marketing in enterprises in Poland and Sri Lanka [75]. The respondents were presidents/directors of companies or heads of marketing departments; if such departments were part of the company structure. The study was quantitative and was based on a questionnaire survey conducted between 2016 and 2017.

Each country surveyed was stratified according to the size of companies, measured by the number of employees. Thus, the following strata were included in the sampling process:

- micro-enterprises, employing up to 10 people;

- small enterprises, employing between 11 and 50 people;

- medium-sized enterprises, employing between 51 and 250 people. 
The sizing of the strata was adjusted in proportion to the value-added created by the SEMs sector. The research was based on 150 interviews conducted in each country. Typical samples in international marketing research oscillate between 200 and 500 organizations, with the sample size from one country being between 50 and 150 [76]. Therefore, a sample of 150 organizations from each surveyed country ensures that the survey is representative. Taking into account the indicated criteria, the structure of entities was established as:

- 55 micro-enterprises,

- 47 small enterprises,

- 48 medium-sized enterprises.

As a result, after the elimination of defective forms, 262 enterprises were considered in the statistical analysis. The sample included 150 Polish respondents (57\% of the sample size) and 112 Sri Lankan respondents ( $43 \%$ of the sample size). Some questionnaires were rejected due to their incorrect completion. The respondents to the study were selected based on the lists of companies published by the Chambers of Commerce in each country and a database of companies was purchased for the purposes of field research. When selecting respondents from the lists, random stratified sampling was used, taking into account the criterion of the company's size. The computer-assisted Web interviewing method was used to obtain the data, as well as computer-assisted telephone interviewing to reach respondents. The average interview time was $33 \mathrm{~min}$.

\subsection{Research Methodology}

It was possible to find answers to the above research questions by analyzing five fundamental elements of the marketing mix, i.e., product, price, place (distribution), promotion (communication), and people (employees) mix from the perspective of their performance concerning sustainable development in each from the countries surveyed. The measurement scale of the marketing mix constructs was based on the research conducted under the supervision of Rudawska within the research project grant financed by the National Science Center in Cracow titled 'Sustainable Marketing Concept and Its Implementation in Selected European Markets: Identification of International Differences', registration no. 2014/14/M/HS4/00891 [51]. This scale included 39 actions that companies could undertake by implementing sustainable marketing tools (Table 1 ). The number of measuring scales used to assess the individual marketing tools was as follows: sustainable product-12; sustainable price —6; sustainable distribution—7; sustainable promotion —7; sustainable people (employees)—7.

Table 1. Measurement of variables.

\begin{tabular}{|c|c|}
\hline \multicolumn{2}{|r|}{ Sustainable Product-PRO } \\
\hline PRO-1 & We focus on products and services, which are of high quality and have a low impact on the environment. \\
\hline PRO-2 & We focus on environmentally friendly packaging. \\
\hline PRO-3 & We reduce the amount of packaging used; i.e., we do not use additional boxes, bags, foil. \\
\hline PRO-4 & We design/choose the packaging with a focus on minimizing transportation costs. \\
\hline PRO-5 & $\begin{array}{l}\text { We focus on clear marketing and advertising communication-we never use incomprehensible, incomplete, } \\
\text { or misleading descriptions suggesting being "eco". }\end{array}$ \\
\hline PRO-6 & We provide full information on the origin of the product's components on the packaging. \\
\hline PRO-7 & We provide full information on the environmental impact of our products on the packaging. \\
\hline PRO-8 & We eliminate pesticides, inorganic fertilizers, chemical additives, etc. in our products. \\
\hline PRO-9 & $\begin{array}{l}\text { We minimize the negative impact of our business on the environment, e.g., by saving energy, } \\
\text { raw materials, etc. }\end{array}$ \\
\hline PRO-10 & We create a brand image that focuses on social and/or environmental prosperity. \\
\hline PRO-11 & $\begin{array}{l}\text { We demonstrate our commitment through social and environmental certifications, e.g., Fair Trade, not tested } \\
\text { on animals, Eco-mark, etc. }\end{array}$ \\
\hline PRO-12 & We use environmental management standards (e.g., ISO 14001, Clean Production program, etc.). \\
\hline
\end{tabular}


Table 1. Cont.

\begin{tabular}{|c|c|}
\hline \multicolumn{2}{|r|}{ Sustainable Price-(PRI) } \\
\hline PRI-1 & We focus on good value for money. \\
\hline PRI-2 & We do not lower our prices below the recommended retail price to increase sales. \\
\hline PRI-3 & Our products/services are more expensive than our competitors because they are sustainable. \\
\hline PRI-4 & $\begin{array}{l}\text { All activities relating to price differentiation are carried out ethically and honestly; e.g., discounts, } \\
\text { geographic diversity, promotional prices. }\end{array}$ \\
\hline PRI-5 & We include the costs of prosocial and proecological actions in the price of our products/services. \\
\hline PRI-6 & We lower the price of our offer through investments in environmentally friendly equipment. \\
\hline \multicolumn{2}{|r|}{ Sustainable Distribution-(DIS) } \\
\hline DIS-1 & Our cooperation with suppliers is based on ethical and fair trade principles \\
\hline DIS-2 & $\begin{array}{l}\text { In choosing suppliers of raw materials/services/half-products we pay special attention to their prosocial } \\
\text { and/or environmental involvement in their daily activities. }\end{array}$ \\
\hline DIS-3 & Our company has a written code of cooperation with business partners (suppliers, intermediaries). \\
\hline DIS-4 & We prioritize the sourcing of raw material from local suppliers. \\
\hline DIS-5 & We pay special attention to the environmental impact of our logistic processes (e.g., carbon footprint). \\
\hline DIS-6 & In choosing suppliers/contractors we always make sure that they are aligned with our principles. \\
\hline DIS-7 & In selecting suppliers/contractors we primarily consider price when agreeing on terms of cooperation. \\
\hline \multicolumn{2}{|r|}{ Sustainable Promotion (Communication)—(COM) } \\
\hline COM-1 & In our company, we engage in charitable and/or sponsorship activities. \\
\hline COM-2 & In the process of communication with customers, we try to promote sustainable consumption. \\
\hline COM-3 & We make sure that our communication with customers is honest and transparent. \\
\hline COM-4 & $\begin{array}{l}\text { We have two-way communication with our customers, asking questions about our products/services, } \\
\text { and guaranteeing our assistance. }\end{array}$ \\
\hline COM-5 & $\begin{array}{l}\text { We regularly inform all stakeholders of our commitment to socioecological activities to build their trust in the } \\
\text { company and our credibility. }\end{array}$ \\
\hline COM-6 & $\begin{array}{l}\text { We regularly train our employees in the social and environmental activities that we undertake so they can } \\
\text { communicate the benefits of sustainable products to customers. }\end{array}$ \\
\hline COM-7 & $\begin{array}{l}\text { We try to replace traditional forms of communication, e.g., leaflets, brochures, and other printed promotional } \\
\text { materials with email, telephone, and social networking. }\end{array}$ \\
\hline \multicolumn{2}{|r|}{ Sustainable People (Employees)—(EMP) } \\
\hline EMP-1 & In our company, we strive to provide employees with a healthy and safe working environment. \\
\hline EMP-2 & $\begin{array}{l}\text { In our company we care about cooperative transparency and openness, implementing codes of ethics as an } \\
\text { expression of concern for respecting employee values and norms. }\end{array}$ \\
\hline EMP-3 & We try to strengthen the attitudes of our staff towards environmental responsibility. \\
\hline EMP-4 & We encourage employees to participate in company developed volunteer programs. \\
\hline EMP-5 & In the first instance, we offer jobs to people from the region when we need to recruit new employees. \\
\hline EMP-6 & We consult with and involve our employees in our strategic planning process. \\
\hline EMP-7 & We have created a work-life balance program. \\
\hline
\end{tabular}

A five-point Likert measurement scale $(1=$ total disagreement; $5=$ total agreement $)$ was used to analyze the degree of acceptance of individual activities constituting the construct measurement scales. The study verified the reliability of the measuring scale, which was estimated using Cronbach's alpha $(\alpha)$. The research showed that for each of the five sustainable marketing mix tools, measurement scales were adopted, which can be considered reliable, as the obtained Cronbach's Alpha index was higher than 0.6 (Table 2). It is widely recognized that the critical value of the indicator, above which the measurement scale can be considered reliable and internally coherent, is $\alpha \leq 0.6$ [77]. 
Table 2. Reliability coefficients for the analyzed constructs.

\begin{tabular}{cc}
\hline Construct & Reliability Coefficient-Cronbach's $\alpha$ \\
\hline Sustainable Product-PRO & 0.89 \\
Sustainable Price-PRI & 0.64 \\
Sustainable Distribution-DIS & 0.77 \\
Sustainable Promotion (Communication_COM) & 0.82 \\
Sustainable People (Employees)_EMP & 0.78 \\
\hline
\end{tabular}

In the process of statistical analysis, basic statistical measures characterizing individual data sets were used, such as measures of central tendency: median (M) and arithmetic mean (X and X (SL + PL) - both countries) and measures of dispersion: standard deviation (S) and coefficient of variation (VS). To examine the differences and similarities between the two groups (countries) of the analyzed enterprises, the nonparametric Mann-Whitney U-test (Z) was used. When making a comparison between two countries, first the calculations were made using the Mann-Whitney $U$ test, then the associated ranks were corrected, hence the formula used for the Mann-Whitney $\mathrm{U}$ test, using the $\mathrm{Z}$ test was calculated from the Formula:

$$
Z=\frac{U-\frac{n_{1} n_{2}}{2}}{\sqrt{\frac{n_{1} n_{2}\left(n_{1}+n_{2}+1\right)}{12}-\frac{n_{1} n_{2} \sum_{i=1}\left(t_{i}^{3}-t_{i}\right)}{12\left(n_{1}+n_{2}\right)\left(n_{1}+n_{2}-1\right)}}}
$$

Z-Z-test result (for the Mann-Whitney $U$ test); $U$-U Mann-Whitney test result; $n_{1}$ - the size of the first group; $n_{2}$-the size of the second group; $t$ - the number of observations with the same rank.

The use of the Mann-Whitney U-test in the study was dictated by the fact that its use is justified when two independent groups are compared, and all observations for both groups are statistically independent. Such conditions are met by the conducted study. Moreover, the Mann-Whitney U-test is not a para-continuous test. This means that the test takes no properties on the distribution of the underlying variables in the analysis. This means that the Mann-Whitney U-test is an analysis used to test variables with an ordinal scale, hence for any pair of variables one can determine their order, confirm their equality, or indicate the greater of them. All these assumptions are in line with the research being carried out, hence the decision was made to use the Mann-Whitney U-test for a comparative analysis of activities related to the implementation of the sustainable marketing mix tools in the two markets: Poland and Sri Lankan. A great diversity of the selected countries in terms of economic development and cultural conditions determines the rationality of carrying out comparative analysis.

Tables 3-7 present final results obtained from the $Z$ test (U Mann-Whitney) together with the significance factor $(p)$, which is necessary to determine the existence or not of statistical differentiation of the examined items. The significance level for the study was $p<0.05$. The data collected was processed using Statistica software. 
Table 3. The assessment and differences in the use of product-related sustainability marketing for Sri Lanka (SL) and Poland (PL).

\begin{tabular}{|c|c|c|c|c|c|c|c|c|c|c|c|c|c|}
\hline \multirow[t]{2}{*}{ No. } & \multirow[t]{2}{*}{ Country } & $\begin{array}{l}\text { Strongly } \\
\text { Agree }\end{array}$ & Agree & $\begin{array}{c}\text { No } \\
\text { Opinion }\end{array}$ & Disagree & $\begin{array}{l}\text { Strongly } \\
\text { Disagree }\end{array}$ & \multirow[t]{2}{*}{$\mathbf{M}$} & \multirow[t]{2}{*}{$\mathrm{S}$} & \multirow[t]{2}{*}{$\mathbf{V}_{\mathbf{s}}$} & \multirow[t]{2}{*}{$X$} & \multirow{2}{*}{$X(S L+P L)$} & \multirow{2}{*}{$\begin{array}{c}\text { Z (U Mann-Whitney } \\
\text { Test) }\end{array}$} & \multirow[t]{2}{*}{ Significance- } \\
\hline & & \multicolumn{5}{|c|}{ Percentage (\%) } & & & & & & & \\
\hline \multirow[b]{2}{*}{ PRO-1 } & SL & 57.9 & 23.0 & 12.7 & 3.2 & 3.2 & 5 & 1.53 & 35.54 & 4.3 & \multirow[b]{2}{*}{4.0} & \multirow[b]{2}{*}{5.3509} & \multirow[b]{2}{*}{0.00} \\
\hline & PL & 19.3 & 50.7 & 24.0 & 0.7 & 5.3 & 4 & 0.95 & 25.06 & 3.8 & & & \\
\hline \multirow[b]{2}{*}{ PRO-2 } & SL & 49.2 & 32.8 & 10.2 & 3.1 & 4.7 & 4 & 1.46 & 34.81 & 4.2 & \multirow[b]{2}{*}{4.0} & \multirow[b]{2}{*}{3.8630} & \multirow[b]{2}{*}{0.00} \\
\hline & PL & 25.3 & 44.0 & 21.3 & 3.3 & 6.0 & 4 & 1.05 & 27.71 & 3.8 & & & \\
\hline \multirow[b]{2}{*}{ PRO-3 } & SL & 34.4 & 28.1 & 23.4 & 6.3 & 7.8 & 4 & 1.50 & 40.02 & 3.8 & \multirow[b]{2}{*}{3.7} & \multirow[b]{2}{*}{1.5445} & \multirow[b]{2}{*}{0.12} \\
\hline & PL & 22.0 & 37.3 & 23.3 & 9.3 & 8.0 & 4 & 1.17 & 32.78 & 3.6 & & & \\
\hline \multirow[b]{2}{*}{ PRO-4 } & SL & 39.1 & 40.6 & 13.3 & 4.7 & 2.3 & 4 & 1.38 & 33.63 & 4.1 & \multirow[b]{2}{*}{3.9} & \multirow[b]{2}{*}{3.0955} & \multirow[b]{2}{*}{0.00} \\
\hline & PL & 22.7 & 46.0 & 20.0 & 2.0 & 9.3 & 4 & 1.13 & 30.39 & 3.7 & & & \\
\hline \multirow[b]{2}{*}{ PRO-5 } & SL & 36.2 & 37.0 & 17.3 & 6.3 & 3.1 & 4 & 1.44 & 36.28 & 4.0 & \multirow[b]{2}{*}{3.9} & \multirow[b]{2}{*}{1.2989} & \\
\hline & PL & 28.0 & 41.3 & 20.7 & 3.3 & 6.7 & 4 & 1.09 & 28.66 & 3.8 & & & 0.19 \\
\hline & SL & 39.4 & 37.8 & 14.2 & 6.3 & 2.4 & 4 & 1.43 & 35.32 & 4.1 & & & \\
\hline PRO-6 & PL & 26.0 & 42.0 & 19.3 & 4.7 & 8.0 & 4 & 1.14 & 30.51 & 3.7 & 3.9 & 2.4798 & 0.01 \\
\hline & SL & 34.4 & 37.5 & 17.2 & 4.7 & 6.3 & 4 & 1.45 & 37.39 & 3.9 & & & \\
\hline PRO-7 & PL & 18.0 & 39.3 & 26.7 & 6.7 & 9.3 & 4 & 1.15 & 32.73 & 3.5 & 3.7 & 3.1794 & 0.00 \\
\hline & SL & 38.6 & 35.4 & 14.2 & 5.5 & 6.3 & 4 & 1.51 & 38.33 & 3.9 & & & \\
\hline PRO-8 & PL & 24.0 & 37.3 & 20.7 & 9.3 & 8.7 & 4 & 1.20 & 33.44 & 3.6 & 3.8 & 2.7827 & 0.01 \\
\hline & SL & 52.8 & 27.6 & 13.4 & 3.9 & 2.4 & 4 & 1.46 & 34.43 & 4.2 & & & \\
\hline PRO-9 & PL & 25.3 & 50.7 & 15.3 & 4.7 & 4.0 & 4 & 0.97 & 25.04 & 3.9 & 4.1 & 3.7180 & 0.00 \\
\hline & SL & 34.6 & 40.9 & 16.5 & 4.7 & 3.1 & 4 & 1.42 & 35.47 & 4.0 & & & \\
\hline PRO-10 & PL & 17.3 & 44.0 & 25.3 & 6.7 & 6.7 & 4 & 1.06 & 29.64 & 3.6 & 3.8 & 3.4394 & 0.00 \\
\hline & SL & 45.7 & 35.4 & 11.8 & 4.7 & 2.4 & 4 & 1.44 & 34.48 & 4.2 & & & \\
\hline PRO-11 & PL & 16.0 & 38.0 & 22.7 & 8.7 & 14.7 & 4 & 1.27 & 38.12 & 3.3 & 3.7 & 6.0502 & 0.00 \\
\hline & SL & 60.9 & 25.0 & 11.7 & 1.6 & 0.8 & 5 & 1.36 & 30.62 & 4.4 & & & \\
\hline PRO-12 & PL & 14.0 & 35.3 & 24.0 & 13.3 & 13.3 & 3 & 1.24 & 38.33 & 3.2 & 3.8 & 8.5870 & 0.00 \\
\hline
\end{tabular}


Table 4. The assessment and differences in the use of price-related sustainability marketing for Sri Lanka (SL) and Poland (PL).

\begin{tabular}{|c|c|c|c|c|c|c|c|c|c|c|c|c|c|}
\hline \multirow[t]{2}{*}{ No. } & \multirow[t]{2}{*}{ Country } & $\begin{array}{l}\text { Strongly } \\
\text { Agree }\end{array}$ & Agree & $\begin{array}{c}\text { No } \\
\text { Opinion }\end{array}$ & Disagree & $\begin{array}{l}\text { Strongly } \\
\text { Disagree }\end{array}$ & \multirow[t]{2}{*}{$\mathbf{M}$} & \multirow[t]{2}{*}{$S$} & \multirow[t]{2}{*}{$\mathbf{V}_{\mathbf{s}}$} & \multirow[t]{2}{*}{$X$} & \multirow[t]{2}{*}{$X(S L+P L)$} & \multirow{2}{*}{$\begin{array}{c}\text { Z (U Mann-Whitney } \\
\text { Test) }\end{array}$} & \multirow[t]{2}{*}{ Significance- $p$} \\
\hline & & \multicolumn{5}{|c|}{ Percentage (\%) } & & & & & & & \\
\hline \multirow[b]{2}{*}{ PRI-1 } & SL & 53.5 & 26.8 & 15.0 & 3.9 & 0.8 & 4 & 1.42 & 33.25 & 4.3 & \multirow[b]{2}{*}{4.1} & \multirow[b]{2}{*}{3.0392} & \multirow[b]{2}{*}{0.00} \\
\hline & PL & 32.2 & 43.6 & 15.4 & 5.4 & 3.4 & 4 & 1.00 & 25.23 & 4.0 & & & \\
\hline \multirow[b]{2}{*}{ PRI-2 } & SL & 29.4 & 31.7 & 27.0 & 7.9 & 4.0 & 4 & 1.46 & 38.97 & 3.7 & \multirow[b]{2}{*}{3.8} & \multirow[b]{2}{*}{-1.0979} & \multirow[b]{2}{*}{0.27} \\
\hline & PL & 27.3 & 46.7 & 16.7 & 6.0 & 3.3 & 4 & 0.99 & 25.39 & 3.9 & & & \\
\hline \multirow[b]{2}{*}{ PRI-3 } & SL & 25.2 & 46.5 & 21.3 & 3.1 & 3.9 & 4 & 1.37 & 35.52 & 3.9 & \multirow[b]{2}{*}{3.6} & \multirow[b]{2}{*}{3.7092} & \multirow[b]{2}{*}{0.00} \\
\hline & PL & 14.9 & 37.2 & 25.0 & 16.9 & 6.1 & 4 & 1.12 & 33.01 & 3.4 & & & \\
\hline \multirow[b]{2}{*}{ PRI-4 } & SL & 41.4 & 35.2 & 14.1 & 5.5 & 3.1 & 4 & 1.44 & 35.55 & 4.0 & \multirow[b]{2}{*}{4.0} & \multirow[b]{2}{*}{1.1677} & \multirow[b]{2}{*}{0.24} \\
\hline & PL & 32.2 & 43.0 & 16.1 & 4.0 & 4.7 & 4 & 1.03 & 26.26 & 3.9 & & & \\
\hline \multirow{2}{*}{ PRI-5 } & SL & 32.8 & 45.3 & 13.3 & 5.5 & 3.1 & 4 & 1.37 & 34.43 & 4.0 & \multirow[b]{2}{*}{3.7} & \multirow{2}{*}{4.1759} & \multirow[b]{2}{*}{0.00} \\
\hline & PL & 14.7 & 46.0 & 18.0 & 11.3 & 10.0 & 4 & 1.17 & 34.09 & 3.4 & & & \\
\hline \multirow[b]{2}{*}{ PRI-6 } & SL & 45.2 & 23.0 & 19.8 & 5.6 & 6.3 & 4 & 1.58 & 39.99 & 4.0 & \multirow[b]{2}{*}{3.7} & \multirow{2}{*}{3.8782} & \multirow{2}{*}{0.00} \\
\hline & PL & 16.1 & 40.9 & 25.5 & 10.7 & 6.7 & 4 & 1.09 & 31.26 & 3.5 & & & \\
\hline
\end{tabular}


Table 5. The assessment and differences in the use of distribution-related sustainability marketing for Sri Lanka (SL) and Poland (PL).

\begin{tabular}{|c|c|c|c|c|c|c|c|c|c|c|c|c|c|}
\hline \multirow[t]{2}{*}{ No. } & \multirow[t]{2}{*}{ Country } & $\begin{array}{l}\text { Strongly } \\
\text { Agree }\end{array}$ & Agree & $\begin{array}{c}\text { No } \\
\text { Opinion }\end{array}$ & Disagree & $\begin{array}{l}\text { Strongly } \\
\text { Disagree }\end{array}$ & \multirow[t]{2}{*}{$\mathbf{M}$} & \multirow[t]{2}{*}{$S$} & \multirow[t]{2}{*}{$\mathbf{V}_{\mathbf{s}}$} & \multirow[t]{2}{*}{$X$} & \multirow[t]{2}{*}{$X(S L+P L)$} & \multirow{2}{*}{$\begin{array}{c}\text { Z (U Mann-Whitney } \\
\text { Test) }\end{array}$} & \multirow[t]{2}{*}{ Significance- $p$} \\
\hline & & \multicolumn{5}{|c|}{ Percentage (\%) } & & & & & & & \\
\hline \multirow[b]{2}{*}{ DIS-1 } & SL & 37.3 & 35.7 & 18.3 & 4.8 & 4.0 & 4 & 1.48 & 37.28 & 4.0 & \multirow[b]{2}{*}{4.0} & \multirow[b]{2}{*}{-0.4968} & \multirow[b]{2}{*}{0.62} \\
\hline & PL & 35.3 & 44.7 & 15.3 & 0.7 & 4.0 & 4 & 0.95 & 23.26 & 4.1 & & & \\
\hline \multirow[b]{2}{*}{ DIS-2 } & SL & 36.8 & 32.8 & 19.2 & 7.2 & 4.0 & 4 & 1.53 & 39.06 & 3.9 & \multirow[b]{2}{*}{3.7} & \multirow[b]{2}{*}{3.0221} & \multirow[b]{2}{*}{0.00} \\
\hline & PL & 14.7 & 48.0 & 22.7 & 8.7 & 6.0 & 4 & 1.04 & 29.13 & 3.6 & & & \\
\hline \multirow[b]{2}{*}{ DIS-3 } & SL & 32.5 & 43.7 & 15.9 & 3.2 & 4.8 & 4 & 1.46 & 36.84 & 4.0 & \multirow[b]{2}{*}{3.9} & \multirow[b]{2}{*}{1.2644} & \multirow[b]{2}{*}{0.21} \\
\hline & PL & 24.7 & 48.7 & 16.0 & 5.3 & 5.3 & 4 & 1.04 & 27.14 & 3.8 & & & \\
\hline \multirow[b]{2}{*}{ DIS-4 } & SL & 42.9 & 30.2 & 17.5 & 4.8 & 4.8 & 4 & 1.53 & 38.02 & 4.0 & \multirow[b]{2}{*}{3.9} & \multirow[b]{2}{*}{1.7910} & \multirow[b]{2}{*}{0.07} \\
\hline & PL & 26.0 & 48.7 & 16.0 & 5.3 & 5.3 & 4 & 1.04 & 27.06 & 3.8 & & & \\
\hline \multirow{2}{*}{ DIS-5 } & SL & 47.6 & 34.9 & 11.1 & 4.8 & 1.6 & 4 & 1.46 & 34.59 & 4.2 & \multirow[b]{2}{*}{4.1} & \multirow[b]{2}{*}{3.2024} & \multirow[b]{2}{*}{0.00} \\
\hline & PL & 26.7 & 48.7 & 17.3 & 3.3 & 4.0 & 4 & 0.96 & 24.70 & 3.9 & & & \\
\hline \multirow[b]{2}{*}{ DIS-6 } & SL & 37.5 & 36.7 & 20.3 & 3.9 & 1.6 & 4 & 1.35 & 33.46 & 4.0 & \multirow[b]{2}{*}{3.9} & \multirow[b]{2}{*}{2.3526} & \multirow[b]{2}{*}{0.02} \\
\hline & PL & 21.3 & 48.7 & 21.3 & 2.7 & 6.0 & 4 & 1.01 & 26.89 & 3.8 & & & \\
\hline & SL & 35.4 & 40.9 & 18.9 & 1.6 & 3.1 & 4 & 1.39 & 34.50 & 4.0 & & & \\
\hline DIS-7 & PL & 22.7 & 54.0 & 14.7 & 3.3 & 5.3 & 4 & 0.99 & 25.58 & 3.9 & 3.9 & 1.6194 & 0.11 \\
\hline
\end{tabular}


Table 6. The assessment and differences in the use of communication-related sustainability marketing for Sri Lanka (SL) and Poland (PL).

\begin{tabular}{|c|c|c|c|c|c|c|c|c|c|c|c|c|c|}
\hline \multirow[t]{2}{*}{ No. } & \multirow[t]{2}{*}{ Country } & $\begin{array}{l}\text { Strongly } \\
\text { Agree }\end{array}$ & Agree & $\begin{array}{c}\text { No } \\
\text { Opinion }\end{array}$ & Disagree & $\begin{array}{l}\text { Strongly } \\
\text { Disagree }\end{array}$ & \multirow[t]{2}{*}{$\mathbf{M}$} & \multirow[t]{2}{*}{$S$} & \multirow[t]{2}{*}{$\mathbf{V}_{\mathrm{s}}$} & \multirow[t]{2}{*}{$X$} & \multirow[t]{2}{*}{$X(S L+P L)$} & \multirow{2}{*}{$\begin{array}{c}\text { Z (U Mann-Whitney } \\
\text { Test) }\end{array}$} & \multirow[t]{2}{*}{ Significance- $p$} \\
\hline & & \multicolumn{5}{|c|}{ Percentage (\%) } & & & & & & & \\
\hline \multirow[b]{2}{*}{ COM-1 } & SL & 32.0 & 45.3 & 16.4 & 3.9 & 2.3 & 4 & 1.34 & 33.42 & 4.0 & \multirow[b]{2}{*}{3.8} & \multirow[b]{2}{*}{3.7756} & \multirow[b]{2}{*}{0.00} \\
\hline & PL & 18.0 & 41.3 & 21.3 & 12.7 & 6.7 & 4 & 1.13 & 32.10 & 3.5 & & & \\
\hline \multirow[b]{2}{*}{ COM-2 } & SL & 33.3 & 46.0 & 15.9 & 2.4 & 2.4 & 4 & 1.40 & 34.55 & 4.1 & \multirow[b]{2}{*}{3.9} & \multirow[b]{2}{*}{3.6581} & \multirow[b]{2}{*}{0.00} \\
\hline & PL & 15.3 & 50.7 & 23.3 & 5.3 & 5.3 & 4 & 0.98 & 26.91 & 3.7 & & & \\
\hline \multirow[b]{2}{*}{ COM-3 } & SL & 40.9 & 40.9 & 11.0 & 4.7 & 2.4 & 4 & 1.42 & 34.28 & 4.1 & \multirow[b]{2}{*}{4.1} & \multirow[b]{2}{*}{1.0795} & \multirow[b]{2}{*}{0.28} \\
\hline & PL & 34.0 & 45.3 & 14.7 & 1.3 & 4.7 & 4 & 0.98 & 24.41 & 4.0 & & & \\
\hline \multirow[b]{2}{*}{ COM-4 } & SL & 43.8 & 37.5 & 12.5 & 3.9 & 2.3 & 4 & 1.39 & 33.29 & 4.2 & \multirow[b]{2}{*}{4.0} & \multirow[b]{2}{*}{2.6550} & \multirow[b]{2}{*}{0.01} \\
\hline & PL & 26.7 & 48.7 & 16.7 & 3.3 & 4.7 & 4 & 0.99 & 25.45 & 3.9 & & & \\
\hline \multirow{2}{*}{ COM-5 } & SL & 35.2 & 39.1 & 20.3 & 3.9 & 1.6 & 4 & 1.34 & 33.36 & 4.0 & \multirow[b]{2}{*}{3.8} & \multirow[b]{2}{*}{4.0750} & \multirow[b]{2}{*}{0.00} \\
\hline & PL & 14.7 & 46.0 & 20.0 & 12.7 & 6.7 & 4 & 1.10 & 31.42 & 3.5 & & & \\
\hline \multirow[b]{2}{*}{ COM-6 } & SL & 33.6 & 42.2 & 14.8 & 7.0 & 2.3 & 4 & 1.38 & 34.63 & 4.0 & \multirow[b]{2}{*}{3.7} & \multirow[b]{2}{*}{3.8534} & \multirow[b]{2}{*}{0.00} \\
\hline & PL & 16.0 & 42.7 & 22.7 & 12.7 & 6.0 & 4 & 1.09 & 31.18 & 3.5 & & & \\
\hline & SL & 33.9 & 37.8 & 18.9 & 3.1 & 6.3 & 4 & 1.47 & 37.75 & 3.9 & & & \\
\hline COM-7 & PL & 23.3 & 44.7 & 16.7 & 8.0 & 7.3 & 4 & 1.14 & 30.81 & 3.7 & 3.8 & 1.6628 & 0.10 \\
\hline
\end{tabular}


Table 7. The assessment and differences in the use of employees-related sustainability marketing for Sri Lanka (SL) and Poland (PL).

\begin{tabular}{|c|c|c|c|c|c|c|c|c|c|c|c|c|c|}
\hline \multirow[t]{2}{*}{ No. } & \multirow[t]{2}{*}{ Country } & $\begin{array}{l}\text { Strongly } \\
\text { Agree }\end{array}$ & Agree & $\begin{array}{c}\text { No } \\
\text { Opinion }\end{array}$ & Disagree & $\begin{array}{l}\text { Strongly } \\
\text { Disagree }\end{array}$ & \multirow[t]{2}{*}{$\mathbf{M}$} & \multirow[t]{2}{*}{$S$} & \multirow[t]{2}{*}{$\mathbf{V}_{\mathrm{s}}$} & \multirow[t]{2}{*}{$X$} & \multirow[t]{2}{*}{$X(S L+P L)$} & \multirow{2}{*}{$\begin{array}{c}\text { Z (U Mann-Whitney } \\
\text { Test) }\end{array}$} & \multirow[t]{2}{*}{ Significance- $p$} \\
\hline & & \multicolumn{5}{|c|}{ Percentage (\%) } & & & & & & & \\
\hline \multirow[b]{2}{*}{ EMP-1 } & SL & 57.0 & 25.8 & 14.1 & 0.8 & 2.3 & 5 & 1.40 & 32.17 & 4.3 & \multirow[b]{2}{*}{4.2} & \multirow[b]{2}{*}{2.6227} & \multirow[b]{2}{*}{0.01} \\
\hline & PL & 35.3 & 51.3 & 8.0 & 2.7 & 2.7 & 4 & 0.87 & 21.13 & 4.1 & & & \\
\hline \multirow[b]{2}{*}{ EMP-2 } & SL & 46.1 & 32.8 & 15.6 & 4.7 & 0.8 & 4 & 1.37 & 32.70 & 4.2 & \multirow[b]{2}{*}{4.0} & \multirow[b]{2}{*}{3.6986} & \multirow[b]{2}{*}{0.00} \\
\hline & PL & 18.0 & 58.0 & 17.3 & 3.3 & 3.3 & 4 & 0.88 & 22.79 & 3.8 & & & \\
\hline \multirow[b]{2}{*}{ EMP-3 } & SL & 33.1 & 44.9 & 13.4 & 4.7 & 3.9 & 4 & 1.42 & 35.70 & 4.0 & \multirow[b]{2}{*}{3.9} & \multirow[b]{2}{*}{1.5264} & \multirow[b]{2}{*}{0.13} \\
\hline & PL & 23.3 & 50.7 & 17.3 & 4.7 & 4.0 & 4 & 0.97 & 25.15 & 3.8 & & & \\
\hline \multirow[b]{2}{*}{ EMP-4 } & SL & 33.6 & 39.8 & 15.6 & 8.6 & 2.3 & 4 & 1.39 & 35.38 & 3.9 & \multirow[b]{2}{*}{3.6} & \multirow[b]{2}{*}{4.4322} & \multirow[b]{2}{*}{0.00} \\
\hline & PL & 14.3 & 38.8 & 22.4 & 13.6 & 10.9 & 4 & 1.20 & 36.12 & 3.3 & & & \\
\hline \multirow[b]{2}{*}{ EMP-5 } & SL & 36.7 & 32.8 & 24.2 & 4.7 & 1.6 & 4 & 1.37 & 34.26 & 4.0 & \multirow[b]{2}{*}{4.0} & \multirow[b]{2}{*}{0.2612} & \multirow[b]{2}{*}{0.79} \\
\hline & PL & 26.2 & 55.0 & 10.1 & 2.0 & 6.7 & 4 & 1.02 & 26.11 & 3.9 & & & \\
\hline \multirow[b]{2}{*}{ EMP-6 } & SL & 44.9 & 35.4 & 13.4 & 5.5 & 0.8 & 4 & 1.41 & 33.63 & 4.2 & \multirow[b]{2}{*}{3.9} & \multirow[b]{2}{*}{4.1422} & \multirow[b]{2}{*}{0.00} \\
\hline & PL & 21.5 & 45.0 & 18.8 & 10.7 & 4.0 & 4 & 1.05 & 28.50 & 3.7 & & & \\
\hline & SL & 48.4 & 35.9 & 6.3 & 7.0 & 2.3 & 4 & 1.43 & 33.86 & 4.2 & & & \\
\hline EMP-7 & PL & 14.1 & 40.3 & 20.1 & 16.1 & 9.4 & 4 & 1.18 & 35.47 & 3.3 & 3.8 & 6.6734 & 0.00 \\
\hline
\end{tabular}




\section{Results}

The conducted study made it possible to verify the implementation of sustainable marketing activities at the operational level, which is closely related to the use of the marketing mix (5P) tools. The research on the implementation of the first tool, which is a sustainable product, indicates that the most popular activity among the interviewed SMEs is minimizing the negative impact of their business on the environment; e.g., by saving energy, water, raw materials, etc. ( $x=4.1$, Table 2, PRO-9). The analysis of the results obtained in both countries shows that such an activity is more important in the developing countries, represented by Sri Lanka $(x=4.2)$, than in the developed countries of Europe, in this study represented by Poland $(x=3.9)$. The next two activities in terms of the popularity of sustainable product use that receive a rating of $x=4.0$ are also significant. The first focuses on products and services, which are of high quality and have a low impact on the environment (Table 2, PRO-1). The next activity concerns focusing on environmentally friendly packaging (Table 2, PRO-2). The results from each country show that both activities are more significant in Sri Lanka $(x=4.3$, $\mathrm{x}=4.2$, respectively) than in Poland ( $\mathrm{x}=3.8$ for both items).

Despite the concern for the environmental friendliness of packaging, the surveyed companies pay little attention to limiting the amount of packaging and minimizing additional boxes, bags, foil, etc., and placing the necessary information on the packaging of the product's environmental impact (for each $\mathrm{x}=3.7$, Table 3, PRO-3, and PRO-7). It is worth noting that there is a large variation between the surveyed countries as for the importance of activities related to the possession and acquisition of service certificates (Table 2, no. PRO-11) and the implementation of environmental management standards (Table 3, PRO-12). Data analysis shows that for Sri Lankan enterprises these are one of the most important activities ( $\mathrm{x}=4.2, \mathrm{x}=4.4$, respectively), and for Polish SMEs the elements were considered the least important $(x=3.3, x=3.2$, respectively).

The analysis of statistically significant differences between the analyzed countries shows that they occur in 10 out of 12 sustainability marketing activities related to the product. No statistically significant difference was noted in the activities related to the reduction of packaging (PRO-3) and those related to the use of incomprehensible or incomplete descriptions suggesting that the product is "eco" that may mislead consumers (PRO-5). The findings show that in all 10 activities, SMEs from Sri Lanka are more active than those from Poland.

The next tool analyzed in terms of implementing sustainable marketing by enterprises was the price. Sustainable price applies to many activities, related not only to economic activities and profit-making, but also the costs of prosocial and proecological activities. The price is a tool that may cause lower interest in purchasing sustainable products among some market segments, as it is often higher than nonecological products. Therefore, pricing strategies should be transparent, fair, and understandable to present customers with the value that has been included in a sustainable price. The analysis shows that the surveyed companies focus their activities on providing good price to the offered value $(\mathrm{x}=4.1$, Table 4 , PRI-1). This measure is used by over $80 \%$ of enterprises in Sri Lanka and over $75 \%$ in Poland. A comparison of the results for each country indicates that it is more important for companies in Sri Lanka $(x=4.3$, Table 3, PRI-4) than in Poland $(x=4.0)$. The concern to maintain the highest standards of honesty in the applied price differentiation strategies $(x=4.0)$ is also of great importance for the examined SMEs. In individual terms, the results show that this action is slightly more important for companies in Sri Lanka $(x=4.0)$ than for those operating in Poland $(x=3.9)$.

The least important place-related sustainability marketing activities for Polish SMEs include those related to setting prices at a higher level than the competition in return for being environmentally friendly $(x=3.4$, Table 3, PRI-3) and taking into account the costs of prosocial and proecological activities in the price of products $(x=3.4$, Table 3, PRI-5). The low popularity of these activities may result from the high sensitivity of Polish consumers to the price of products and the lack of willingness to incur higher costs for sustainable products. Among companies in Sri Lanka, these activities are more popular $(x=3.9 ; x=4.0$, respectively). However, among the managers of these companies, a lower 
commitment was identified in not lowering prices to excessively increase the sales of products $(x=3.7$, for Poland $x=3.9$ ).

Four of the six factors analyzed were found to have statistically significant differences between the responses of managers from Sri Lanka and Poland (Table 4) related to PRI-1, PRI-3, PRI-5, PRI-6. The results of the study show that in all four activities, enterprises in Sri Lanka are more active than those in Poland.

When considering another sustainable marketing tool called distribution (place), the activities related to the selection of suppliers, means of transport, terms of cooperation with contractors, and their prosocial and proecological activities were taken into account. The analysis of the results of the use of distribution-related sustainability marketing shows that the most popular activity among the surveyed SMEs is the optimization of logistics processes that are related to the selection of transport routes, the use of relatively new and economical means of transport, and their optimal loading $(x=4.1$, Table 5, DIS-5). This measure is more popular among SMEs in Sri Lanka, where almost $83 \%$ of the surveyed managers supported this measure, giving it a minimum rating of 4 , while in Poland it is $75 \%$. The second most frequently supported activity of sustainable distribution is establishing cooperation with suppliers, which is fair and based on ethical principles $(x=4.0$, Table 4 , DIS-1). This activity is of slightly higher importance among Polish enterprises $(x=4.1)$ than those in Sri Lanka $(x=4.0)$. It can be noticed that for the two measures discussed, the differentiation of responses among Polish managers was lower (respectively $\mathrm{V}_{\mathrm{s}}=24.70, \mathrm{~V}_{\mathrm{s}}=23.26$ ), while the opinions of respondents in Sri Lanka were more varied (respectively $\mathrm{V}_{\mathrm{s}}=34.28, \mathrm{~V}_{\mathrm{s}}=37.28$ ).

Among the analyzed factors, the least important in the implementation of sustainable distribution is the selection of suppliers, taking into account their prosocial and/or proecological involvement in everyday activities. In both analyzed countries, it was the least important, i.e., $x=3.9$ for Sri Lanka, $\mathrm{x}=3.6$ for Poland.

Statistically significant differences were observed in three of the seven variables (Table 5): DIS-2, DIS-5, DIS-6. As for all the three indicated activities, the research shows that SMEs from Sri Lanka show greater involvement than those from Poland.

As already indicated, the study also considers activities related to the implementation of sustainable communication. Promotional strategies in sustainable marketing are aimed at familiarizing stakeholders with the proecological and prosocial activities of the company. Such communication is based mainly on honest dialogue, while companies in their activities both support charity and strive to conduct promotional activities with care for the environment. The results of the research indicate that for the surveyed managers, the most important thing is to ensure that the communication with clients is honest, reliable, and transparent $(x=4.1$, Table 6, COM-3). The analysis of the countries separately shows that this measure is significant for each country ( $x=4.1$ for Sri Lanka, $x=4.0$ for Poland). Among the respondents in Sri Lanka, activities that facilitate two-way communication with clients, giving them the opportunity of asking questions to which they can get answers, were considered even more important. In this country, over $81 \%$ gave a positive answer, while in Poland this figure fluctuated around $75 \%$ of enterprises. In both discussed activities, the coefficient of variation indicates a stronger discrepancy in the responses of Sri Lankan managers (respectively, $V_{\mathrm{s}}=34.28, \mathrm{~V}_{\mathrm{s}}=33.29$ ) than the responses obtained from respondents in Poland, whose results were not significantly differentiated (respectively $\mathrm{V}_{\mathrm{s}}=24.41, \mathrm{~V}_{\mathrm{s}}=25.45$ ).

Statistically large differentiation of activities between countries with different socioeconomic development was noted in five out of the seven measures. They were COM-1, COM-2, COM-4, COM-5, COM-6 (Table 6). It is worth noting that there is a large disproportion of the responses of the results obtained between the countries for the actions COM-1, COM-5, COM-6. It shows that companies in Sri Lanka engage in charity and/or sponsorship activities $(x=4.0)$, attach greater importance to building trust among stakeholders by communicating their prosocial and proeconomic commitment $(x=4.0)$, and it is also important for them to regularly train their employees to familiarize them with 
the sustainable features of the products sold $(x=4.0)$. While the indicated actions obtained a high score in Sri Lanka, in Poland each of these elements were rated the lowest (each at $x=3.5$ ).

The final sustainability marketing tool kit that was included in the study was people. Activities aimed at the company's employees are an important factor in the sustainable development of the company. In this area, the key companies surveyed considered providing their employees with healthy and safe working conditions ( $x=4.2$, Table 7, EMP-1). In Sri Lanka, 83\% and in Poland, $87 \%$ of the managers indicated this as significant. Another element that SMEs prioritize in their employee-focused activities is a concern for transparency, and openness to cooperation by creating ethical codes that are followed with care $(x=4.0)$. The analysis of each country individually indicates that a higher weighting is assigned to this measure in the Asian country $(x=4.2)$, however, the coefficient of variation indicates a higher differentiation of the responses $\left(\mathrm{V}_{\mathrm{s}}=32.70\right)$. In the analyzed European country, managers were more unanimous $\left(\mathrm{V}_{\mathrm{s}}=22.79\right)$, but the obtained responses indicate that less importance is assigned to the organization's culture and ethical codes $(x=3.8)$. Another activity considered significant in both analyzed countries is giving priority to the inhabitants of the region during the recruitment process ( $x=4.0$ in Sri Lanka, $x=3.9$ in Poland).

The analysis of the results shows the existence of statistical differences between the countries in five out of the seven items. They concern the activities EMP-1, EMP-2, EMP-4, EMP-6, EMP-7. It is noteworthy that there is a large disproportion in the importance of activities related to EMP-4 and EMP-7. They show that while Sri Lankan managers consider it important to encourage employees to participate in the company's volunteering programs $(x=3.9)$ and to create Work-Life Balance programs for employees to maintain harmony between private and professional life $(x=4.2)$, for Polish SMEs, these items are assessed as one of the least important of all sustainable marketing activities (for each $x=3.3)$.

\section{Discussion}

Marketing in modern companies plays a much more central role [33]. As emphasized by Rudawska [1], the situation when environmental and social aspects are gaining more and more importance, companies face the need to respond to changing customer needs, new regulations, and new social orders, which is the result of anxiety about the consequences of business in the social and environmental aspect. The increase in the importance of sustainable development requires significant changes in the company's activities in the area of management and marketing. According to Duić et al. [78], there is an urgent need to develop new concepts, approaches, and methods for sustainable development, including tools that are applicable in business. Proper use of marketing tools that take into account sustainability seems to be crucial in the process of transformation of enterprises. Appropriate management of the redefined marketing mix by company managers aims to consider values in the three areas and it concerns the building of financial, natural, and social capital based on the concept of sustainable development [79]. The conducted research shows that the implementation of sustainable marketing activities requires initiatives in many areas of the company's activity. Sustainability in the surveyed countries is not only a well-promoted ecological offer, but also it is seen in activities that are sometimes not directly visible to customers, e.g., investment in fair relationships with suppliers, the use of eco-raw materials during production, or the concern for good and safe working conditions for employees. The research in the food and beverage sector also indicates that different tools are used with different levels of commitment.

The main tool of a sustainable marketing strategy is the product. According to Fuller [38], a sustainable product has ecological features that are created based on decisions about the method of production, the use of materials from which the product was made, the method of operation, duration of use, distribution, use, and the possibility of recalling the product to the last life cycle. The research carried out in the article confirms the great importance attached by company managers to activities related to the product. They attach particular importance to minimizing the negative impact of products on the environment, including the saving of raw materials such as water, energy. The research shows 
that these activities are much more significant in the Sri Lankan market than in Poland. In addition to the environmental aspect, the social issues that may be related to production, such as decent working conditions and the policy of purchasing raw materials, are also significant for buyers. Therefore, it is important to provide consumers with consistent information, both in the environmental and social areas. As emphasized in their research by Becot et al. [39], buyers expect ethical behavior from enterprises, high-quality, healthy, and safe products, ecological packaging, reliable information, and fair advertising. The research conducted by the author of the article shows that the SME study places great importance on creating high-quality products with a low negative impact on the environment. The use of ecological packaging is also an important factor in their strategies.

A significant aspect of the implementation of sustainable marketing by enterprises is the use of sustainable prices. As Martin and Schouten [32] emphasize, sustainable prices take full account of production and marketing costs, not only in economic terms but also in environmental and social terms, while providing consumers with benefits and profits for the producer. On the one hand, higher prices of sustainable products may limit the implementation of sustainable marketing activities. On the other hand, however, the growing awareness and heightened expectations of customers and business partners make the implementation of sustainable development activities almost obligatory for the competitive functioning of enterprises. Research conducted by Willer and Kilcher [68] indicate that customers are willing to pay more for products that are produced by a farming method supporting a healthy agroecosystem and do not use environmentally harmful agrochemicals. The conducted research shows that the most important factor for the surveyed companies is providing customers with good value for money. Nevertheless, the results of the study show that the activities related to higher prices than the competition in return for offering environmentally friendly products are used by Polish managers quite rarely, which may suggest the reluctance of Polish consumers to incur higher costs.

Distribution is another important tool in sustainable marketing activities. In the food and beverage industry, it is concerned with the provision of environmental and social aspects of infrastructure, including transport and storage [45]. Sustainable distribution includes not only the choice of environmentally friendly means of transport but also thoughtful planning of routes to shorten the distance necessary to deliver products, by creating local supply chains [80]. The research carried out by the author shows that among all activities related to sustainable distribution, SME managers consider paying special attention to the creation of ecological distribution processes as the most important. Leonidou et al. [44] emphasize that companies implementing marketing should also ensure that their suppliers and distributors operate ethically and ecologically, that their products are local, and the prices are fair. This is confirmed by the research conducted by the author, in which one of the key factors indicated by managers is the cooperation based on honesty and ethical actions, which is more important for Polish managers than for those of the Sri Lankan market.

Another tool of sustainable marketing is sustainable promotion, the main task of which is to support the activities carried out by the company. As Peattie [49] emphasizes that sustainable communication is not only about conveying positive information about the offer, but also about conducting a dialogue in which the company is involved. The communication activities used in the food and beverage industry inform of the company's sustainable activities and create its image, but also enable entrepreneurs to educate consumers and encourage them to make proecological and prosocial consumer choices and actions. The analysis of the collected data in the study conducted by the author shows the actual involvement of companies in communication, for which the most important aspect was the transparency of messages and honesty of information. Managers in the food and beverage sector pay special attention to a two-way communication with the customer. There is a much stronger emphasis on sustainable communication among enterprises on the Sri Lankan market than among the Polish ones.

The last analyzed tool for sustainable marketing is employees. Charter et al. [81] emphasize that an integral part of business sustainability is the fact that 'people are the business' and they have to implement change. As emphasized by Certo and Creto [52], activities related to the implementation of sustainable marketing concern creating lasting and long-term communication with employees. 
Activities connected with this tool of sustainability marketing were divided into three principal groups: compliance with labor rights; ensuring organizational order, manifested through transparency and openness, ethical behavior towards employees, priority in offering work to residents, etc.; ensuring proper relations with employees by integrating them around sustainability initiatives, consulting employees about sustainability marketing strategies [82]. Of great importance in the activities of the surveyed companies is the focus on employment conditions that are healthy and safe, as well as on creating conditions conducive to the development of employees. The results of the study show that managers attach great importance to the transparency and ethicality of cooperation with employees, which may have an impact on building real and long-term relationships with them.

The conducted research shows that between the two analyzed markets (Polish and Sri Lankan ones) there are statistically significant differences in the perception of the essence of the implementation of various marketing activities consistent with the concept of sustainable development. The aim of the article has been achieved in this area. The analysis of the obtained results shows, however, that the implementation of activities in the context of sustainable marketing is much more important among SME managers in Sri Lanka than in Poland. In the light of these results, it has not been confirmed that in the developed countries-where the concept of sustainable development has been present for a longer time - sustainable marketing contributes to the intensification of activities in the field of its implementation to a greater extent than in the developing countries. The obtained results indicate that in the Sri Lankan market, activities in the field of marketing tools are important elements of the strategies of the companies. Among 39 sustainable items characteristic for five marketing mix tools (product-12; price - 6; distribution-7; communication-7; employees-7), 27 of them obtained the result of $x=4.0$ and more. For comparison, in the Polish market, such a result was obtained by four actions.

In the Sri Lankan market, two of the four considered the most important activities concerned a sustainable product (PRO-12, PRO-1). The surveyed managers considered the implementation of environmental management standards to be the most important. It is worth emphasizing that among Polish managers, this action obtained the lowest result among 39 analyzed items. The second, slightly less important activity in the product area in the Sri Lankan market was the concentration of activities on creating the highest quality products with their minimal negative impact on the natural environment. The analysis of the hierarchy of importance indicates that an important element in the SMEs in the Sri Lankan market is sustainable employee-focused activities. Priority is given to activities that are targeted at employees and aim to provide them with healthy and safe working conditions. Significant importance is also attached to the price level of the offer, which should take into account its actual value. The obtained results can be seen in the characteristics of the culture of a given country, which is oriented towards the example of a collectivist society. Strong social bonds and concerns for the welfare of the future generations also take into account stronger care for the natural environment. Actions resulting from this approach have been identified in the activity of SME managers in Sri Lanka.

On the Polish market, there was less acceptance of and involvement in activities related to the implementation of sustainable marketing. However, the factors that were indicated as the most important out of all 39 are worth noting. The analysis shows that Polish managers attach great importance to building relationships with various stakeholders. This can be seen in the case of employees, as special attention is paid to activities aimed at ensuring good working conditions for employees. As for building relationships with suppliers, honest cooperation based on ethical principles is of great importance to the Polish market. The third place in terms of importance was placed on customer relationships, which according to the respondents, should be based on transparent, honest, and reliable communication. The importance of honesty towards customers is also reflected in the price level, which according to the respondents, should take into account the real value of the products.

In conclusion, it should be stated that apart from contributing to the economic development of the nations, manufacturers have a key strategic role to play in ensuring fair trade between the nations and the future food security against the combined effects of climate change, higher global demand, and increasing pressure on finite resources [83]. 


\section{Conclusions}

The results described in this article may have an impact on existing research in the area of marketing and sustainability research in several ways. Firstly, they provide a new definition of sustainable market tools that are adapted by SMEs. The research results can have a significant practical application, as it indicates 39 sustainable marketing activities, which constitute a specific hint of solutions that can be incorporated into the company's development strategy. The literature strongly emphasized the lack of research for entities of this size, as the research conducted so far has focused on research on large entities [35]. The list of specific measures to implement may be a solution for SMEs, and it may be an impulse for more active implementation of sustainable marketing in the structures of enterprises. Secondly, the research conducted in the food and beverage industry shows the specificity of this industry and the opportunity of adapting the activities important to this sector. Many authors emphasize the need to research individual sectors, examining sustainable marketing [61]. Thirdly, the conducted research facilitates the identification of key activities undertaken by SMEs to implement the concept of sustainable marketing in each of the five marketing mix tools operating on the Polish and Sri Lankan markets. Finally, the conducted research makes it possible to identify differences in activities that are significantly and still insufficiently implemented in two socioeconomically diverse markets. It can be valuable information regarding which of the particular areas should be strengthened by the SMEs operating in a given area.

The conducted research also has its limitations, which also set the directions for future research. Firstly, the study was conducted in one economic sector (the food and beverage sector). The delimitation of the study allowed, however, to indicate the specificity of SMEs operating in a given industry but, on the other hand, dependencies in other industries may differ from the obtained results of the study. Hence, in the future, it is worth conducting a similar study on other sectors of the economy. The second limitation results from the study of one representative of a developed country and one of a developing country. As a result, the obtained results may be characteristic for these specific countries, not for all countries with given socioeconomic factors. Therefore, an interesting area for further research would be the verification of individual activities on a larger number of markets to show the existing dependencies. Thirdly, these studies were declaratory and therefore carry the risk of human error. In the future, more in-depth case studies are advised to be carried out. Moreover, the study was conducted on cross-sectional data, which hinders real observation of the results and changes taking place in companies, as well as changes in activities in a given market. An interesting direction of the future research would be to conduct a longitudinal study that would indicate changes in the implementation of the concept of sustainable marketing among SMEs in particular markets.

Funding: This research is financed within the framework of the program of the Minister of Science and Higher Education under the name "Regional Excellence Initiative" in the years 2019-2022; project number 001/RID/2018/19; the amount of financing PLN 10,684,000.00.

Conflicts of Interest: The author declares no conflict of interest.

\section{References}

1. Rudawska, E. Sustainable marketing strategy in food and drink industry: A comparative analysis of B2B and B2C SMEs operating in Europe. J. Bus. Indust. Mark. 2019, 34, 875-890. [CrossRef]

2. Inigo, E.; Albareda, L.; Ritala, P. Business model innovation for sustainability: Exploring evolutionary and radical approaches through dynamic capabilities. Indust. Innov. 2017, 24, 515-542. [CrossRef]

3. Demil, B.; Lecocq, X. Business model evolution: In search of dynamic consistency. Long Range Plan. 2010, 43, 227-246. [CrossRef]

4. Ulvenblad, P.; Ulvenblad, P.; Tell, J. An overview of sustainable business models for innovation in Swedish agri-food production. J. Integr. Environ. Sci. 2019, 16, 1-22. [CrossRef]

5. Upward, A.; Jones, P. An ontology for strongly sustainable business models: Defining an enterprise framework compatible with natural and social science. Organ. Environ. 2016, 29, 97-123. [CrossRef]

6. Holden, E. Achieving Sustainable Mobility: Everyday and Leisure-Time Travel in the EU; Ashgate: Aldershot, UK, 2007. 
7. Parnwell, M.; Bryant, R. Environmental Change in South-East Asia. People, Politics and Sustainable Development; Routledge: New York, NY, USA, 1998.

8. Agrawal, A.K.; Kumar, D.; Rahman, Z. An ISM approach for modelling the enablers of sustainability in market-oriented firms. Int. J. Bus. Excell. 2017, 12, 23-45. [CrossRef]

9. Fonseca, L.; Ferro, R. Does it pay to be social responsible? Portuguese SMEs feedback. Intang. Cap. 2016, 12, 487-505. [CrossRef]

10. Kolk, A. The social responsibility of international business: From ethics and the environment to CSR and sustainable development. J. World Bus. 2016, 51, 23-34. [CrossRef]

11. Freudenreich, B.; Lüdeke-Freund, F.; Schaltegger, S.A. Stakeholder theory perspective on business models: Value creation for sustainability. J. Bus. Ethics 2019, 1, 1-16. [CrossRef]

12. Dangelici, R.M.; Vocalelli, D. "Green Marketing": An analysis of definitions, strategy steps, and tools through a systematic review of the literature. J. Clean. Product. 2017, 165, 1263-1279. [CrossRef]

13. Kordshouli, H.R.; Ebrahimi, A.; Bouzanjani, A.A. An analysis of the green response of consumers to the environmentally friendly behaviour of corporations. Iran. J. Manag. Stud. 2015, 8, 315-334.

14. Davari, A.; Strutton, D. 'Marketing mix strategies for closing the gap between green consumers' pro environmental beliefs and behaviors. J. Strat. Mark. 2014, 22, 563-586. [CrossRef]

15. Chang, N.J.; Fong, C.M. Green product quality, green corporate image, green customer satisfaction, and green customer loyalty. Afr. J. Bus. Manag. 2010, 4, 2836-2844.

16. Martin, D.; Schouten, J. Consumption-Driven Market Emergence. J. Cons. Res. 2014, 40, 855-887. [CrossRef]

17. Hartmann, P.; Apaolaza Ibáñez, V. Green value added. Mark. Intell. Plan. 2006, 24, 673-680. [CrossRef]

18. Goi, C.L. A Review of Marketing Mix: 4Ps or More? Int. J. Mark. Stud. 2009, 1, 1-14. [CrossRef]

19. Möller, K. The Marketing Mix Revisited: Towards the 21st Century Marketing by E. constantinides. J. Mark. Manag. 2006, 22, 439-450. [CrossRef]

20. Papadas, K.K.; Avlonitis, G.J.; Carrigan, M. Green marketing orientation: Conceptualization, scale development and validation. J. Bus. Res. 2017, 80, 236-246. [CrossRef]

21. Borland, H.; Lindgreen, A. Sustainability, epistemology, ecocentric business, and marketing strategy: Ideology, reality, and vision. J. Bus. Ethics 2012, 117, 173-187. [CrossRef]

22. Nkamnebe, A.D. Sustainability marketing in the emerging markets: Imperatives, challenges, and agenda setting. Int. J. Emerg. Mark. 2011, 6, 217-232. [CrossRef]

23. Heath, M.T.P.; Chatzidakis, A. Blame it on marketing: Consumers views on unsustainable consumption. Int. J. Consum. Stud. 2012, 36, 656-667. [CrossRef]

24. Brundtland and World Commission on Environment and Development. Our Common Future: Report of the World Commission on Environment and Development; Oxford University: Oxford, UK, 1987.

25. Pomering, A. Marketing for sustainability: Extending the conceptualization of the marketing mix to drive value for individuals and society at large. Australas. Mark. J. 2017, 25, 157-165. [CrossRef]

26. Pomering, A.; Johnson, L.W. Building Sustainability into Services Marketing: Expanding Decision-Making from a Mix to a Matrix. Sustainability 2018, 10, 2992. [CrossRef]

27. Kenning, P. Sustainable Marketing_Definition und begriffliche Abgrenzung. In Sustainable Marketing Management. Grundlagen und Cases; Meffert, H., Kenning, P., Kirchgeorg, M., Eds.; Springer Gabler: Wiesbaden, Germany, 2014; pp. 3-20.

28. Hunt, S.D. Sustainable marketing, equity, and economic growth: A resource-advantage, economic freedom approach. J. Acad. Mark. Sci. 2011, 39, 7-20. [CrossRef]

29. Belz, F.M. Sustainability Marketing: Blueprint of a Research Agenda, Marketing and Management in a Food Industry; Discussion Paper; TUM Business School: Freising, Germany, 2005; p. 1.

30. Kirchgeorg, M.; Winn, M.I. Sustainability marketing for the poorest of the poor. Bus. Strat. Environ. 2006, 15, 171-184. [CrossRef]

31. Kemper, J.A.; Hall, C.M.; Ballantine, P.W. Marketing and Sustainability: Business as Usual or Changing Worldviews? Sustainability 2019, 11, 780. [CrossRef]

32. Martin, D.; Schouten, J. Sustainable Marketing; Pearson Prentice Hall: Upper Saddle River, NJ, USA, 2012.

33. Kumar, V.; Rahman, Z.; Kazmi, A.A. Stakeholder identification and classification: A sustainability marketing perspective. Manag. Res. Rev. 2016, 39, 35-61. [CrossRef]

34. Kotler, P. Re-Inventing Marketing to Manage the Environmental Imperative. J. Mark. 2011, 75, 4. [CrossRef] 
35. Finch, J.H.; Geiger, S.; Harkness, R.J. Marketing and compromising for sustainability: Competing orders of words in the North Atlantic. Mark. Theory 2017, 17, 71-93. [CrossRef]

36. Yang, D. What Should SMEs Consider to introduce environmentally innovative products to market? Sustainability 2019, 11, 1117. [CrossRef]

37. Tseng, S.-C.; Hung, S.-W. A framework identifying the gaps between customers' expectations and their perceptions in green products. J. Clean. Prod. 2013, 59, 174-184. [CrossRef]

38. Fuller, D.A. Sustainable Marketing: Managerial_Ecological Issues; SAGE: Thousand Oaks, CA, USA, 1999.

39. Becot, F.; Conner, D.; Nelson, A.; Buckwalter, E.; Erickson, D. Institutional Demand for Locally-Grown Food in Vermont: Marketing Implications for Producers and Distributors. J. Food Distrib. Res. 2014, 45, 1-19.

40. Esmaili, M.; Fazeli, S.F. Surveying of importance of green marketing compared purchase budget and preferred brand when buying by AHP method. Mediterr. J. Soc. Sci. 2015, 6, 388-394.

41. Michaud, C.; Llerena, D. Green consumer behaviour: An experimental analysis of willingness to pay for remanufactured products. Bus. Strateg. Environ. 2011, 20, 408-420. [CrossRef]

42. Essoussi, L.H.; Linton, J.D. New or recycled products: How much are consumers willing to pay? J. Consum. Mark. 2010, 27, 458-468. [CrossRef]

43. Lee, C.K.; Lee Lam, J.S. Managing reverse logistics to enhance sustainability of industrial marketing. Ind. Market. Manag. 2012, 41, 589-598. [CrossRef]

44. Leonidou, C.N.; Katsikeas, C.S.; Morgan, N.A. Greening the marketing mix: Do firms do it and does it pay off? J. Acad. Mark. Sci. 2013, 41, 151-170. [CrossRef]

45. Gallo, A.; Accorsi, R.; Baruffaldi, G.; Manzini, R. Designing Sustainable Cold Chains for Long-Range Food Distribution: Energy-Effective Corridors on the Silk Road Belt. Sustainability 2017, 9, 2044. [CrossRef]

46. Rademaker, C.A.; Royne, M.B.; Wahlund, R. Eco-harmful media perceptions and consumer response to advertising. J. Clean. Prod. 2015, 108, 799-807. [CrossRef]

47. Kronrod, A.; Grinstein, A.; Wathieu, L. Go green! Should environmental messages be so assertive? J. Mark. 2012, 76, 95-102.

48. Shields, J.; Shelleman, J.M. Integrating sustainability into SME strategy. J. Small Bus. Strat. 2015, 25, 59-76.

49. Peattie, K. Environmental Marketing Management: Meeting the Green Challenge; Pearson Education Print on Demand Edition; Pearson Education Limited: Harlow, UK, 1995.

50. Grimmer, M.; Bingham, T. Company environmental performance and consumer purchase intentions. J. Bus. Res. 2013, 66, 1945-1953. [CrossRef]

51. Rudawska, E. The Sustainable Marketing Concept in European SMEs; Emerald Group Publishing Ltd.: Bingley, UK, 2018.

52. Certo, S.C.; Certo, S.T. Modern Management: Concepts and Skills; Pearson: Upper Saddle River, NJ, USA, 2015.

53. Darcy, C.; Hill, J.; McCabe, T.J.; McGovern, P. A consideration of organizational sustainability in the SME context: A resource-based view and composite model. Eur. J. Train. Dev. 2014, 38, 398-414. [CrossRef]

54. Ferro, C.; Padin, C.; Svensson, G.; Varela, J.C.S.; Wagner, B.; Høgevold, N.M. Validating a framework of stakeholders in connection to business sustainability efforts in supply chains. J. Bus. Indust. Mark. 2017, 32, 124-137. [CrossRef]

55. Loucks, E.S.; Martens, M.L.; Cho, C.H. Engaging small- and medium-sized businesses in sustainability. Sustain. Account. Manag. Policy J. 2010, 1, 178-200. [CrossRef]

56. Haanaes, K.; Balagopal, B.; Arthur, D.; Kong, M.T.; Velken, I.; Kruschwitz, N.; Hopkins, M.S. First look: The second annual sustainability \& innovation survey. MIT Sloan Manag. Rev. 2011, 52, 76-83.

57. Lawrence, S.R.; Collins, E.; Pavlovich, K.; Arunachalam, M. Sustainability practices of SMEs: The case of NZ. Bus. Strat. Environ. 2006, 15, 242-257. [CrossRef]

58. Wang, J.; Zhang, Y.; Goh, M. Moderating the Role of Firm Size in Sustainable Performance Improvement through Sustainable Supply Chain Management. Sustainability 2018, 10, 1654. [CrossRef]

59. Govindan, K. Sustainable consumption and production in the food supply chain: A conceptual framework. Int. J Prod. Econ. 2018, 195, 419-431. [CrossRef]

60. Reisch, L.; Eberle, U.; Lorek, S. Sustainable food consumption: An overview of contemporary issues and policies. Sustainability 2013, 9, 7-25. [CrossRef]

61. Lee, K.H. Why and how to adopt green management into business organizations? The case study of Korean SMEs in the manufacturing industry. Manag. Decis. 2009, 47, 1101-1121. [CrossRef] 
62. ResearchAndMarkets. Food and Beverages Global Market Report 2020-30: COVID-19 Impact and Recovery. 2020. Available online: www.researchandmarkets.com (accessed on 10 December 2020).

63. FoodDrinkEurope. A Competitive EU Food and Drink Industry for Growth and Jobs: Ambitions for 2025-Priorities and Policy Recommendations. 2016. Available online: www.fooddrinkeurope.eu (accessed on 10 December 2020).

64. Lanteigne, M. China and International Institutions, Alternative Paths to Global Power; Routledge: London, UK; New York, NY, USA, 2005.

65. Gössling, S.; Hall, C.M.; Peeters, P.; Scott, D. The Future of Tourism: Can Tourism Growth and Climate Policy be Reconciled? A Mitigation Perspective. Tour. Recreat. Res. 2010, 35, 119-130. [CrossRef]

66. Yakovleva, N.; Sarkis, J.; Sloan, T. Sustainable Benchmarking of Supply Chains: The Case of the Food Industry. Int. J. Prod. Res. 2012, 50, 1297-1317. [CrossRef]

67. Friel, S.; Barosh, L.J.; Lawrence, M. Towards Health and Sustainable Food Consumption: An Australian Case Study. Pub. Health Nutri. 2014, 17, 1156-1166. [CrossRef]

68. Willer, H.; Kilcher, L. (Eds.) The World of Organic Agriculture. Statistics and Emerging Trends; IFOAM: Bonn, Germany; FiBL: Frick, Switzerland, 2009.

69. Capitanio, F.; Coppola, A.; Pascucci, S. Product and Process Innovation in the Italian Food Industry. Agribusiness 2010, 26, 503-518. [CrossRef]

70. Ruggeri, A.; Arvola, A.; Samoggia, A.; Hendrixson, V. Food Behaviours of Italian Consumers at Risk of Poverty. Br. Food J. 2015, 117, 2831-2848. [CrossRef]

71. Hall, E.T.; Hall, M.R. Understanding Cultural Differences, Intercultural; Intercurtural Press: Yarmouth, ME, USA, 1990.

72. World Economic Outlook. Recovery Strengthens, Remains Uneven; International Monetary Fund: Washington, DC, USA, 2014. Available online: www.imf.org/en/publications/weo/issues/2016/12/31/recovery-strengthensremains-uneven (accessed on 2 November 2020).

73. Hofstede Insights. Available online: https://www.hofstede-insights.com/ (accessed on 2 November 2020).

74. Balyaeva, Z. Busines environment challenges and trends for contemporary SMEs in Europe. In The Sustainable Marketing Concept in European SMEs; Rudawska, E., Ed.; Emerald Group Publishing Ltd.: Bingley, UK, 2018; pp. 13-28.

75. Rudawska, E. The Perception of Sustainable Marketing Concept by SME Managers in Selected European and Asian Countries. Entrep. Manag. 2019, 20, 351-364.

76. Karcz, K. International Marketing Research: Cultural Determinants; PWE: Warsaw, Poland, 2004.

77. Hair, J.F.; Black, W.C.; Babin, B.J.; Anderson, R.E.; Tatham, R.L. Multivariate Data Analysis, 7th ed.; Prentice Hall: Upper Saddle River, NJ, USA, 2015.

78. Duić, N.; Urbaniec, K.; Huisingh, D. Components and structures of the pillars of sustainability. J. Clean. Prod. 2015, 88, 1-12. [CrossRef]

79. Muñoz-Pascual, L.; Curado, C.; Galende, J. The Triple Bottom Line on Sustainable Product Innovation Performance in SMEs: A Mixed Methods Approach. Sustainability 2019, 11, 1689. [CrossRef]

80. Engelseth, P. Developing Exchange in Short Local Foods Supply Chains. Int. J. Food Syst. Dyn. 2016, 7, $229-242$.

81. Charter, M.; Peattie, K.; Ottman, J.; Polonsky, M.J. Marketing and Sustainability. Centre for Business Relationships, Accountability, Sustainability and Society (BRASS), in Association with the Centre for Sustainable Design. Available online: http://www.research.ucreative.ac.uk/693/1/smart-know-net.pdf (accessed on 10 December 2020).

82. Rudawska, E.; Putek-Szelag, E.; Leusmann, U. Differences and similarities in approach to sustainable marketing tools used by smes in the food and drink sector in selected European countries. Org. Rev. 2018, 5, 28-34.

83. Lodorfos, G.; Konstantopoulou, A.; Essien, E.E. Food and Drink Industry in Europe and Sustainability Issues: Insights from the Food \& Drink Industry. In The Sustainable Marketing Concept in European SMEs; Rudawska, E., Ed.; Emerald Group Publishing Ltd.: Bingley, UK, 2018; pp. 121-140.

Publisher's Note: MDPI stays neutral with regard to jurisdictional claims in published maps and institutional affiliations. 